\title{
ABX203, a novel
}

\section{therapeutic vaccine}
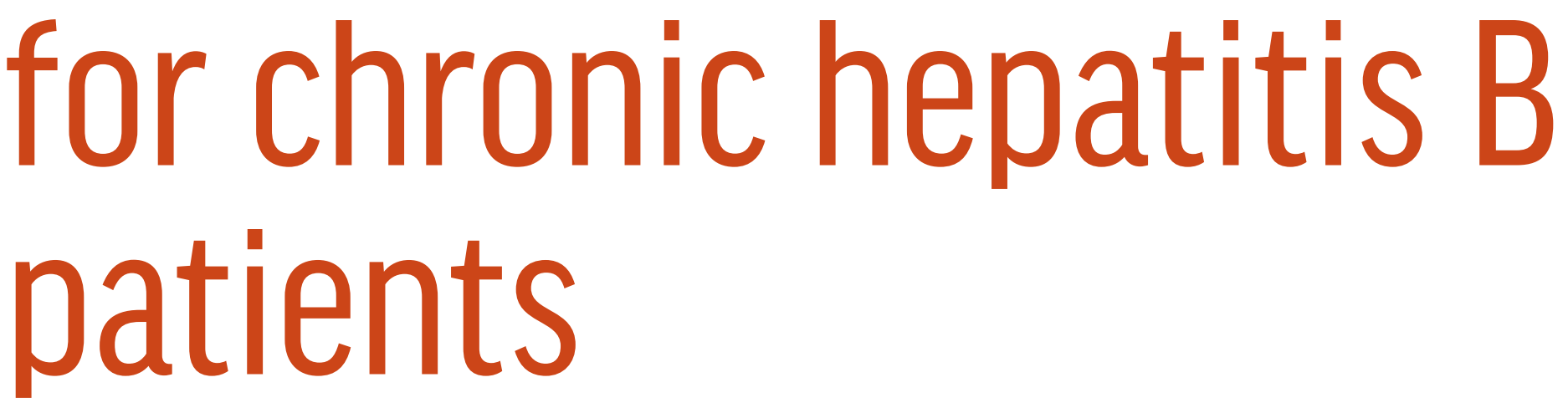

\section{Lobaina Mato Y.' • Aguilar Rubido J.C.' • Guillén Nieto G.E.'}

Lobaina Mato Yadira - PhD, Researcher, Hepatitis B therapeutic vaccine Project, Vaccine Department, Biomedical Research Unit $^{1}$

Aguilar Rubido Julio Cesar - PhD, Senior Researcher, Head of Hepatitis B therapeutic vaccine Project, Vaccine Department, Biomedical Research Unit ${ }^{1}$

Guillen Nieto Gerardo Enrique - PhD,

Member of the Cuban Academy of

Science, Senior Researcher, Biomedical Research Director ${ }^{1}$

$\triangle 31$ Avenue, P.O. Box 6162, Havana 6,

10 600, Cuba. Tel: (53-7) 2504495.

E-mail: gerardo.guillen@cigb.edu.cu
Despite the existence of effective prophylactic vaccines, chronic hepatitis $B$ remains a major public health problem, with more than 350 million people infected worldwide. Chronic infection increases the risk of serious liver diseases such as cirrhosis and hepatocellular carcinoma. Available therapies for chronic hepatitis B have limited efficacy and require long-term continuous treatments; that is why the development of therapeutic vaccines has been investigated as promising approach. In this sense, a novel vaccine formulation called ABX203 (HeberNasvac), based on the combination of the hepatitis $B$ virus nucleocapsid and surface antigens, was developed. ABX203 has been studied in phase I, phase II and phase III clinical trial in treatment-naïve chronically infected patients in Bangladesh and in healthy volunteers in Cuba with promising results. In the present work we reviewed the main preclinical and clinical results of ABX203 development. Altogether, the data demonstrates safety and immunogenicity of $A B X 203$ vaccine and support its use as a novel and competitive treatment alternative for chronic hepatitis B. The vaccine has been granted marketing authorization in Cuba.

Key words: $A B X 203$, hepatitis $B$, vaccine doi: 10.18786/2072-0505-2016-44-6-713-718

${ }^{1}$ Center for Genetic Engineering and Biotechnology (CIGB); Avenue 31, P.O. Box 6162, Havana 6, 10 600, Cuba 


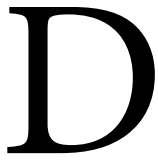
espite almost universal vaccination of neonates and infants in more than 180 countries, with more than $80 \%$ coverage and the subsequent reduction in the incidence of new infections with hepatitis B virus (HBV), chronic HBV infection remains a significant public health problem worldwide. Nowadays more than 350 million people are persistently infected, and two billion people show evidence of past or current infection. These individuals act as a reservoir for viral spread. Chronic infection also increases the risk of severe liver complications such as cirrhosis and hepatocellular carcinoma. One million people die each year worldwide as a consequence of chronic hepatitis B (CHB) complications [1].

Currently available treatments for CHB include the use of standard and pegylated interferon alpha (Peg-IFN), and several nucleos(t)ide analogues, such as lamivudine, adefovir, telbivudine, entecavir, and tenofovir. Less than half of World Health Organization's Member States included antiviral drugs in the essential medication list [1]. These antiviral therapies are not effective for HBV elimination; they require long treatments and induce undesirable side effects [2].

Viral persistence has been associated with a defect in the development of HBV-specific cellular immunity. Limitations of the currently available therapies underline the need for alternative ones. Specific immunotherapeutic strategies target not only the induction or stimulation of CD4(+) and CD8(+) T-cell responses, but also the induction of pro-inflammatory cytokines capable of controlling viral replication. The use of vaccine formulations in the treatment of $\mathrm{CHB}$ constitutes an attractive approach. The first generation of $\mathrm{CHB}$ therapeutic vaccine was based on the use of hepatitis B surface antigen (HBsAg) formulations similar to the current HBV prophylactic vaccines. Although this strategy induces an effect on $\mathrm{CHB}$ patients, the immune response generated was not completely effective and sustained [3,4]. More recently, several clinical trials have been performed using different vaccine formulations; however none of them has demonstrated a sufficient level of clinical efficacy [5].

ABX203 (HeberNasvac) was developed by the Center for Genetic Engineering and Biotechnology from Cuba. The vaccine is based on a combination of the HBsAg and the HBV nucleocapsid ( $\mathrm{HBcAg}$ ) antigens and is simultaneously administered by the intranasal and subcutaneous routes [6,7]. ABX203 has been studied in phase I, phase II and phase III clinical trials with promising results [8-10]. In the present work we reviewed the results of the main preclinical and clinical trials of this product.

\section{Rationale for ABX203 vaccine design}

The working hypothesis of this product suggests that repeated administration of ABX203, simultaneously administered by intranasal and subcutaneous routes to CHB patients, would be able to subvert the HBV specific immune tolerance, inducing specific immune responses (specifically Th1-related) in systemic and mucosal compartments, as well as the activation of antigen presenting cell (APC) to a level enough to control viral replication and normalize the transaminases in a significant number of patients, without severe adverse reactions.

The inclusion of the complete $\mathrm{HBcAg}$ as a virus-like nucleoparticle in the formulation allows the development of a more potent and multifaceted immune response [3]. The anti-HBcAg specific cellular response has been associated with HBV control [11]. It has been also described that HBcAg induces a Th1pattern of immune response [12], which correlates with the immune response required for $\mathrm{HBV}$ control $[13,14]$. In addition, the recombinant $\mathrm{HBcAg}$ present in ABX203 vaccine has the capacity to encapsulate bacterial nucleic acid, which acts as a potent Th1 adjuvant [12]; all these properties circumvent the need in external adjuvant in the formulation.

Other novelty of ABX203 vaccine formulation is the use of the intranasal route of administration. Involvement of the mucosal immune system in response to ABX203 vaccine allows stimulating a new pool of immune cells that could be less affected by the HBV tolerance established in chronic patients [15]. The fact that both antigens in the formulation (HBsAg and $\mathrm{HBcAg}$ ) are virus-like particles around 20-30 $\mathrm{nm}$ in diameter [16] facilitates their uptake by nasopharyngeal physiological mechanisms [17]. In addition, the combination of parenteral and mucosal routes for the vaccine administration constitutes another approach to further potentiate the immune response in chronic patients. This strategy has been recently used with promising results in HIV vaccine studies $[18,19]$.

\section{Pharmacological studies in animal models}

Immunogenicity of ABX203 has been extensively studied in normal and transgenic mice [6, 7, 20-23]. In Balb/c mice, immunogenicity of this combination formulation at different doses and antigen ratios was explored using parenteral and mucosal immunization routes $[6,7,20,24]$. In these studies ABX203 formulation induced a potent humoral immune response against both antigens and secretion of interferon 
gamma (IFN- $\gamma)$ by $\mathrm{T} \mathrm{CD}^{+}$cells. A strong lymphoproliferative response in total spleen cells was also detected. A similar behavior was observed in C57/ Bl6 mice [6]. Knowing the relevance of the IFN- $\gamma$ secretion response as the main effector mechanism for HBV control in humans $[25,26]$, these results support the evaluation of ABX203 formulation as a potential effective treatment against $\mathrm{CHB}$.

In addition, immune response induced by ABX203 immunization was also studied in hepatitis B transgenic mice models [21-23]. Two different transgenic mice models of $\mathrm{CHB}$ were used. The first model showed high levels of HBsAg expression in blood and some organs [27]. However, a humoral and cellular immune response against the $\mathrm{HBsAg}$ could be detected after five doses of ABX203 using the intranasal/subcutaneous combined schedule for the immunizations $[21,28]$. Other authors reported difficulties to induce a HBsAg-specific immune response in hepatitis B transgenic mice with the use of potent adjuvanted formulations [29, 30]. Considering this point and high levels of HBsAg present in the circulation of the currently employed transgenic mice, the results pointed out the promising profile of ABX203 vaccine. Additionally, it is important to say that any potential damage that could be generated by a strong immune response in mice expressing HBsAg in their main organs, such as liver and kidneys, was evaluated in various histopathological studies (with up to 25 immunizations); no evidence of toxicity was observed $[21,22,28]$. Using the same transgenic model, a number of complementary studies on adoptive transfer of ABX203 immune splenocytes was carried out. The results obtained confirm the immunogenicity and safety profile of ABX203 vaccination strategy [22]. ABX203 formulation has been also evaluated in a humanized hepatitis B surface antigen transgenic mouse model [23, 31]. These studies demonstrate that ABX203 formulation is capable to elicit humoral immune response against both antigens and a predominantly $\mathrm{T} \mathrm{CD} 4^{+}$ cellular immune response. In general, the results obtained in transgenic mice indicate recovery of T-cell function mediated by antiviral cytokine production, such as TNF- $\alpha$ and INF- $\gamma$.

Being analyzed together, the preclinical data obtained with ABX203 indicates that this vaccine candidate is highly immunogenic and shows good evidence of immune stimulation in $\mathrm{CHB}$ infection animal models.

\section{Toxicological studies}

To support the safety profile of ABX203 formulation, several toxicological studies have been performed fulfilling Good Laboratory Practice requirement. Table 1 summarizes general characteristics of each study. Altogether, this battery of toxicological studies demonstrated safety and tolerability of ABX203 use by intranasal route alone or with simultaneous subcutaneous administrations.

\section{Clinical phase of development}

So far, several clinical trials with ABX203 vaccine have been carried out (Table 2). All volunteers gave

Table 1. Toxicological studies carried out for HeberNasvac safety evaluation

\begin{tabular}{|c|c|c|}
\hline Study & Animal specie & Route \\
\hline Acute toxicity & Sprague Dawley rats & Intranasal \\
\hline Irritability & Sprague Dawley rats & Intranasal \\
\hline Local tolerance & Sprague Dawley rats & Intranasal \\
\hline Acute toxicity - single dose & Sprague-Dawley rats & Intranasal \\
\hline Acute toxicity - single dose & Sprague Dawley rats & Intranasal/subcutaneous simultaneous administration \\
\hline Local tolerance & Sprague Dawley rats & Intranasal/subcutaneous simultaneous administration \\
\hline Repeated doses & Sprague Dawley rats & Intranasal/subcutaneous simultaneous administration \\
\hline Acute toxicity - single dose & $\begin{array}{l}\text { First generation rabbits (New Zealand } \times \text { Semi- } \\
\text { Giant) }\end{array}$ & Intranasal/subcutaneous simultaneous administration \\
\hline Repeated doses & $\begin{array}{l}\text { First generation rabbits (New Zealand × Semi- } \\
\text { Giant) }\end{array}$ & Intranasal/subcutaneous simultaneous administration \\
\hline
\end{tabular}


Table 2. Completed clinical trials with HeberNasvac

\begin{tabular}{|c|c|c|c|c|c|}
\hline Study & Study subjects & N & HeberNasvac doses & Route & Reference \\
\hline $\begin{array}{l}\text { Randomized, double blind, } \\
\text { placebo controlled Phase I }\end{array}$ & Healthy adult & 19 & $\begin{array}{l}5 \text { doses }(50 \mu g \text { of } \\
\text { each antigen per } \\
\text { dose) }\end{array}$ & Intranasally & [8] \\
\hline Open-label Phase I/II & $\begin{array}{l}\text { CHB patients refractory or } \\
\text { intolerant to IFN-a }\end{array}$ & 6 & $\begin{array}{l}10 \text { doses }(100 \mu g \text { of } \\
\text { each antigen per } \\
\text { dose) }\end{array}$ & Intranasally & Unpublished \\
\hline Open-label Phase I/II & Treatment-naïve $\mathrm{CHB}$ patients & 18 & $\begin{array}{l}10 \text { doses }(100 \mu \mathrm{g} \text { of } \\
\text { each antigen per } \\
\text { route) }\end{array}$ & $\begin{array}{l}5 \text { doses } \\
\text { intranasally }+5 \text { doses } \\
\text { intranasally / } \\
\text { subcutaneously }\end{array}$ & [9] \\
\hline $\begin{array}{l}\text { Randomized, open-label, } \\
\text { Peg-IFN controlled } \\
\text { Phase III }\end{array}$ & Treatment-naïve $\mathrm{CHB}$ patients & 160 & $\begin{array}{l}10 \text { doses }(100 \mu \mathrm{g} \text { of } \\
\text { each antigen per } \\
\text { route) }\end{array}$ & $\begin{array}{l}5 \text { doses } \\
\text { intranasally }+5 \text { doses } \\
\text { intranasally / } \\
\text { subcutaneously }\end{array}$ & [10] \\
\hline
\end{tabular}

CHB chronic hepatitis B, IFN- $a$ interferon alpha, Peg-IFN pegylated interferon

their written informed consent before enrollment, and the studies were conducted according to the principles set in the Declaration of Helsinki and in accordance with Good Clinical Practice requirements.

First, the vaccine was evaluated in a phase I trial in healthy male adults [8]. In this initial trial all the adverse events reported were categorized as mild in intensity and self-limiting. The rates of adverse events observed were similar or below those reported for other commercial products with intranasal administration, Nasal-flu and calcitonin spray $[32,33]$. Additionally, $100 \%$ seroconversion was attained against $\mathrm{HBCAg}$ and a $75 \%$ against the surface antigen. These results were encouraging and suggested that the intranasal administered dose could be increased to obtain a higher humoral immune response. This clinical trial with ABX203 vaccine was the first ever to demonstrate seroprotection in healthy adult individuals against HBV after intranasal administration.

Later on two clinical trials were conducted in $\mathrm{CHB}$ patients in Cuba and Bangladesh to evaluate preliminary safety and efficacy. The Cuban study enrolled six patients previously treated with interferon- $\alpha$, showing detectable levels of viral load at the start of vaccination (unpublished data). These six patients received a vaccination schedule of ten doses each, intranasally. The trial demonstrated that ABX203 was safe and well tolerated. At the end of the study, all patients demonstrated a reduction in their viral load to undetectable levels (assessed quantitatively). The viral load remained constantly reduced up to three years after the end of treatment. In addition, signals of serological response against the HBeAg were observed in three patients who were HBeAg-positive at the beginning of the study.

The phase I/II trial in Bangladesh enrolled 18 treatment-naïve patients [9]. The vaccine was administered ten times at 2-weekly intervals, the first five doses via nasal route only and the subsequent five doses via both nasal and subcutaneous routes. This study demonstrated the safety profile of ABX203 administered simultaneously by intranasal and subcutaneous routes. No flare-ups of HBV DNA or alanine aminotransferase were recorded in any patient. In general, sustained transaminases normalization was observed in $100 \%$ of patients, followed by a significant reduction of viral load to undetectable levels in $50 \%$ of them. Moreover, an increment in secretion of pro-inflammatory cytokines was observed after the end of the first treatment cycle.

Subsequently, a randomized, open-label, treatment controlled Phase III trial was carried out in Bangladesh [10]. A total of $160 \mathrm{CHB}$ patients were enrolled and randomly assigned to receive either a ABX203 therapeutic vaccine or Peg-IFN. The vaccine administration schedule was similar to the described above for the phase I/II trial. Treatment with Peg-IFN was used as a control, at dose regimen of 180 microgram subcutaneously once weekly for 48 consecutive weeks. The results confirmed safety of ABX203 therapeutic immunization; no serious or severe adverse events were detected. In terms of efficacy, $61 \%$ of $\mathrm{ABX} 203$ treated patients reduced their HBV DNA levels below 250 copies/mL (undetectable HBV DNA) at end of treatment and a similar proportion remained undetectable after 24 weeks of treatment-free follow up. In the Peg-IFN group, 
$67 \%$ of patients reduced their HBV DNA levels below 250 copies $/ \mathrm{mL}$ at end of treatment; however, only $39 \%$ remained at the same level after 24 weeks of treatment-free follow up. A generalized and sustained normalization of alanine aminotransferase values in the majority of patients was observed. These promising results support future clinical trials with ABX203.

In summary, the clinical data obtained demonstrated safety of ABX203. The most frequent systemic adverse events were flu-like symptoms. At local level, sneezing and rhinorrhea after intranasal administrations and pain at injection site after subcutaneous administrations were registered. In terms of efficacy, the main achievements of the product are a significant and sustained off-treatment reduction of the viral load, and normalization of transaminase levels in all treated patients.

\section{Conclusion}

Altogether, the results provide the strong evidence that vaccination with ABX203 (HeberNasvac) is safe and efficacious, supporting its use for therapy of $\mathrm{CHB}$ infection. (8)

\section{Acknowledgements}

Authors would like to thank all the research team from Cuba and Bangladesh working in the development of HeberNasvac vaccine.

\section{Литература / References}

1. World Health Organization. Global policy report on the prevention and control of viral hepatitis in WHO Member States. Geneva: WHO Press; 2013. 208 p. Available from: http://apps.who.int/iris/bitstre am/10665/85397/1/9789241564632_eng.pdf.

2. Gish RG, Given BD, Lai $C L$, Locarnini $S A$, Lau JYN, Lewis DL, Schluep T. Chronic hepatitis B: Virology, natural history, current management and a glimpse at future opportunities Antiviral Res. 2015;121:47-58. doi: 10.1016/j.antiviral.2015.06.008.

3. Vandepapeliere P, Lau GK, Leroux-Roels G, Horsmans $Y$, Gane E, Tawandee $T$, bin Merican MI, Win KM, Trepo C, Cooksley G, Wettendorff $M$, Ferrari $C$; Therapeutic HBV Vaccine Group of Investigators. Therapeutic vaccination of chronic hepatitis $B$ patients with virus suppression by antiviral therapy: A randomized, controlled study of co-administration of $\mathrm{HBsAg} / \mathrm{ASO} 2$ candidate vaccine and lamivudine. Vaccine. 2007;25(51):8585-97. doi: 10.1016/j.vaccine.2007.09.072.

4. Aguilar JC, Lobaina Y. Immunotherapy for chronic hepatitis B using $\mathrm{HBsAg}$ based vaccine formulations: from preventive commercial vaccines to therapeutic approach. Euroasian J Hepato-Gastroenterol. 2014;4(2):53-8. doi: 10.5005/jp-journals-10018-1109.

5. Michel ML, Deng $Q$, Mancini-Bourgine $M$. Therapeutic vaccines and immune-based therapies for the treatment of chronic hepatitis B: Perspectives and challenges. J Hepatol. 2011;54(6):1286-96. doi: 10.1016/j. jhep.2010.12.031.

6. Aguilar JC, Lobaina Y, Muzio V, Garcia D, Penton $E$, Iglesias $E$, Pichardo D, Urquiza D, Rodriguez D, Silva $D$, Petrovsky N, Guillen G. Development of a nasal vaccine for chronic hepatitis B infection that uses the ability of hepatitis $B$ core antigen to stimulate a strong Th1 response against hepatitis $B$ surface antigen. Immunol Cell Biol. 2004;82(5):539-46. doi: 10.1111/j.0818-9641.2004.01278.x.

7. Lobaina $Y$, Trujillo $H$, Garcia D, Gambe A, Chacón Y, Blanco A, Aguilar JC. The effect of the parenteral route of administration on the immune response to simultaneous nasal parenteral immunizations using a new HBV therapeutic vaccine candidate. Viral Immunol. 2010;23(5):521-9. doi: 10.1089/vim.2010.0024.

8. Betancourt AA, Delgado CA, Estévez ZC, Martínez JC, Ríos GV, Aureoles-Roselló SR, Zaldívar RA, Guzmán MA, Baile NF, Reyes PA, Ruano LO, Fernández AC, Lobaina-Matos $Y_{\text {, }}$ Fernández AD, Madrazo Al, Martínez $\mathrm{Ml}$, Baños $\mathrm{ML}$, Alvarez NP, Baldo MD, Mestre RE, Pérez MV, Martínez ME, Escobar DA, Guanche MJ, Cáceres LM, Betancourt RS, Rando EH, Nieto GE, González VL, Rubido JC. Phase I clinical trial in healthy adults of a nasal vaccine candidate containing recombinant hepatitis B surface and core antigens. Int J Infect Dis. 2007;11(5):394-401. doi: 10.1016/j. ijid.2006.09.010.

9. Al-Mahtab M, Akbar SM, Aguilar JC, Uddin H, Khan SI, Rahman S. Therapeutic potential of a combined hepatitis B virus surface and core antigen vaccine in patients with chronic hepatitis B. Hepatol Int. 2013;7(4):981-9. doi: 10.1007/s12072-013-9486-4.

10. Akbar SM, Al-Mahtab M, Rahman S, Aguilar JC, Hiasa Y, Mishiro S. A phase III clinical trial with a therapeutic vaccine containing both $\mathrm{HBsAg}$ and $\mathrm{HBCAg}$ administered via both mucosal and parenteral routes in patients with chronic hepatitis B. Hepatology. 2013;58(S1):647A705A. doi: 10.1002/hep.26727.

11. Lau GK, Suri D, Liang R, Rigopoulou El, Thomas MG, Mullerova I, Nanji A, Yuen ST, Williams R, Naoumov NV. Resolution of chronic hepatitis $B$ and anti-HBs seroconversion in humans by adoptive transfer of immunity to hepatitis B core antigen. Gastroenterology. 2002;122(3):614-24. doi: http://dx.doi. org/10.1053/gast.2002.31887.

12. Riedl P, Stober D, Oehninger C, Melber K, Reimann J, Schirmbeck R. Priming Th1 Immunity to Viral Core Particles Is Facilitated by Trace Amounts of RNA Bound to Its Arginine-Rich Domain. J Immunol. 2002;168(10):4951-9. doi: 10.4049/jimmunol.168.10.4951.
13. Bertoletti A, Naoumov NV. Translation of immunological knowledge into better treatments of chronic Hepatitis B. J Hepatol. 2003;39(1):11524. doi: 10.1016/S0168-8278(03)00126-0.

14. Bertoletti A, Ferrari C. Innate and adaptive immune responses in chronic hepatitis $B$ virus infections: towards restoration of immune control of viral infection. Gut. 2012;61(12):1754-64. doi: 10.1136/gutjnl-2011-301073.

15. Davis SS. Nasal vaccines. Adv Drug Deliv Rev. 2001;51(1-3):21-42. Available from: http://dx. doi.org/10.1016/S0169-409X(01)00162-4.

16. Liaw YF, Chu CM. Hepatitis B virus infection. Lancet. 2009;373(9663):582-92. doi: 10.1016/ S0140-6736(09)60207-5.

17. Holmgren J, Czerkinsky C. Mucosal immunity and vaccines. Nat Med. 2005;11(4 Suppl):S45-53. doi: 10.1038/nm1213.

18. Vajdy $M$, Singh $M$, Kazzaz J, Soenawan E, Ugozzoli M, Zhou F, Srivastava I, Bin Q, Barnett $S$, Donnelly J, Luciw P, Adamson L, Montefiori D, O'Hagan DT. Mucosal and systemic anti-HIV responses in rhesus macaques following combinations of intranasal and parenteral immunizations. AIDS Res Hum Retroviruses. 2004;20(11):1269-81. doi: 10.1089/ aid.2004.20.1269.

19. Makitalo B, Lundholm P, Hinkula J, Nilsson C, Karlen K, Morner A. Enhanced cellular immunity and systemic control of SHIV infection by combined parenteral and mucosal administration of a DNA prime MVA boost vaccine regimen. J Gen Virol. 2004;85(Pt 8):2407-19. doi: 10.1099/vir.0.79869-0.

20. Lobaina Y, Palenzuela D, Pichardo D, Muzio V, Guillen G, Aguilar JC. Immunological characterization of two hepatitis $B$ core antigen variants and their immunoenhancing effect on co-delivered hepatitis B surface antigen. Mol Immunol. 2005;42(3):289-94. doi: 10.1016/j. molimm.2004.09.005.

21. Trujillo H, Blanco A, Garcia D, Freyre F, Aguiar J, Lobaina Y, Aguilar JC. Optimization of a therapeutic vaccine candidate by studying routes, immunizations schedules and antigen doses in $\mathrm{HBsAg-positive} \mathrm{transgenic} \mathrm{mice.} \mathrm{Euroa-}$ 
sian J Hepato-Gastroenterol. 2014;4(2):70-8. doi: 10.5005/jp-journals-10018-1105.

22. Lobaina Y, García D, Blanco A, Hernández D, Trujillo H, Freyre F, Merino N, Suarez J, Ancizar J, Martinez L, Aguilar JC. The adoptive transfer of $\mathrm{HBsAg}$-specific splenocytes from BALB/c congenic donors into HBsAg transgenic mice is not associated to histopathological damage. Euroasian J Hepato-Gastroenterol. 2013;3(2):97102. doi: 10.5005/jp-journals-10018-1074.

23. Bourgine M, Dion S, Godon O, Guillen G, Michel ML, Aguilar JC. Optimization of immune responses induced by therapeutic vaccination with cross-reactive antigens in a humanized hepatitis B surface antigen transgenic mouse model. Virology. 2012;430(1):10-9. doi: 10.1016/j.virol.2012.04.007.

24. Lobaina Y, Garcia D, Rodriguez D, La OY, Aguilar JC. Characterization of the immune response generated in mice by intramuscular administration of a formulation containing the nucleocapsid and surface antigen of hepatitis B. Biotecnologia Aplicada. 2010;27(3):211-5.

25. Maini MK, Boni C, Lee CK, Larrubia JR, Reignat $S$, Ogg GS, King AS, Herberg J, Gilson R, Alisa A, Williams R, Vergani D, Naoumov NV, Ferrari C, Bertoletti A. The role of virus-specific
CD8 (+) cells in liver damage and viral control during persistent hepatitis $B$ virus infection. J Exp Med. 2000;191(8):1269-80. doi: 10.1084/ jem.191.8.1269.

26. Yang PL, Althage A, Chung J, Maier H, Wieland $S$, Isogawa $M$, Chisari FV. Immune effectors required for hepatitis $B$ virus clearance. Proc Natl Acad Sci U S A. 2010;107(2):798-802. doi: 10.1073/pnas.0913498107.

27. Castro FO, Perez A, Aguilar A, de la Riva G, Martinez R, de la Fuente J, Herrera L. Expresión del gen del antigeno de superficie del virus de la hepatitis $B$ en ratones transgénicos. Interferon y Biotecnología. 1989;6(3):251-7 (in Spanish).

28. Freyre F, Blanco A, Trujillo $H$, Hernandez D, Garcia D, Alba J, Lopez M, Merino N, Lobaina Y, Aguilar JC. Dynamic of immune response induced in hepatitis B surface antigen-transgenic mice immunized with a novel therapeutic formulation. Euroasian J Hepato-Gastroenterol. 2016;6(1):25-30. doi: 10.5005/jp-journals-10018-1161.

29. Schirmbeck R, Wild J, Stober D, Blum HE, Chisari FV, Geissler M, Reimann J. Ongoing murine T1 or $\mathrm{T} 2 \mathrm{immune}$ responses to the hepatitis B surface antigen are excluded from the liver that expresses transgene-encoded hepatitis B sur- face antigen. J. Immunol. 2000;164(8):423543. doi: 10.1111/j.1348-0421.2003.tb03370.x.

30. Shimizu Y, Guidotti LG, Fowler P, Chisari FV. Dendritic cell immunization breaks cytotoxic T lymphocyte tolerance in hepatitis $B$ virus transgenic mice. J. Immunol. 1998;161(9):4520-9.

31. Mancini-Bourgine $M$, Guillen $G$, Michel $M L$, Aguilar JC. Impact of the immunogen nature on the immune response against the major HBV antigens in an HBsAg and HLA-humanized transgenic mouse model. Euroasian J Hepato-Gastroenterol. 2014;4(1):36-44. doi: 10.5005/jp-journals-10018-1094.

32. Downs RW, Bell NH, Ettinger MP, Walsh BW, Favus MJ, Mako B, Wang L, Smith ME, Gormley GJ, Melton ME. Comparison of Alendronate and intranasal Calcitonin for treatment of osteoporosis in postmenopausal women. J Clin Endocrinol Metab. 2000;85(5):1783-8. doi: 10.1210/jcem.85.5.6606.

33. Nichol KL, Mendelman PM, Mallon KP, Jackson LA, Gorse GJ, Belshe RB, Glezen WP, Wittes J. Effectiveness of live, attenuated intranasal influenza virus vaccine in healthy, working adults: a randomized controlled trial. JAMA. 1999;282(2):137-44. doi: 10.1001/ jama.282.2.137.

\title{
АВХ203, инновационная
}

\section{терапевтическая вакцина для больных} хроническим гепатитом B

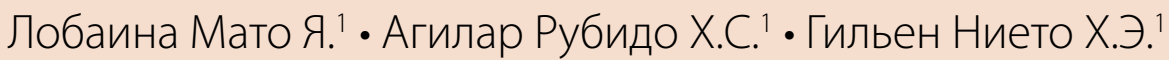

Несмотря на существование эффективной вакцинопрофилактики, хронический гепатит В, которым во всем мире инфицировано более 350 млн человек, остается одной из основных проблем здравоохранения. Хроническая инфекция увеличивает риск серьезной печеночной патологии - цирроза и гепатоцеллюлярного рака. Существующие методы лечения хронического гепатита В недостаточно эффективны и требуют длительной непрерывной терапии. Вот почему в качестве перспективного подхода изучается возможность разработки терапевтических вакцин. В этих целях был создан инновационный вакцинальный препарат ABХ203 (Назвак), в состав которого входят сердцевинный (HBcAg) и поверхностный (HBsAg) антигены вируса гепатита В. Терапевтическая двухкомпонентная вакцина АBX203, зарегистрированная на Кубе, изучалась в клинических исследованиях I, II и III фазы у ранее не леченных хронически инфицированных пациентов в Бангладеш и у здоровых добровольцев на Кубе и показала многообещающие результаты. Эта статья представляет собой обзор основных результатов доклинических и клинических исследований вакцины АВХ203. На основании анализа представленных данных можно говорить о безопасности и иммуногенности вакцины ABX203, что позволяет применять ее как инновационный и конкурентоспособный вариант лечения хронического гепатита В.

Ключевые слова: ABX203, гепатит В, вакцина

doi: 10.18786/2072-0505-2016-44-6-713-718
Лобаина Мато Ядира - д-р наук, науч. сотр., проект разработки терапевтической вакцины против гепатита B, отдел вакцин, департамент биомедицинских научных исследований'

Агилар Рубидо Хулио Сезар - д-р наук, ст. науч. сотр., руководитель проекта разработки терапевтической вакцины против гепатита $\mathrm{B}$, отдел вакцин, департамент биомедицинских научных исследований

Гильен Нието Херардо Энрике - д-р наук, действительный член Кубинской академии наук, ст. науч. сотр., директор по биомедицинским исследованиям'

$\triangle$ Gerardo Guillén, Biomedical Research Direction, Center for Genetic Engineering and Biotechnology (CIGB). 31 Avenue, P.O. Box 6162, Havana 6, 10 600, Cuba. Tel: (53-7) 2504495.

E-mail: gerardo.guillen@cigb.edu.cu
'Центр генной инженерии и биотехнологии; 10 600, Гавана 6, 31-я Авеню, п/я 6162, Куба 